\title{
Philosophy of Sustainable Development: Utopia or Ideal? The historic excursus into the traditional worldview of peoples of Eurasia
}

\author{
Assel Dadyrova ${ }^{1,}{ }^{*}$, Gaini Mukhtarova ${ }^{1}$, Zhanna Omarova $^{1}$
}

${ }^{1}$ Kazakh National University of Arts, 010000, 50 Tauelsizdik Ave, Nur-Sultan, Kazakhstan

\begin{abstract}
The article is devoted to the theme of the transition of mankind from a society of «intellectual moral decline» to a society of «awareness by each individual of personal planetary responsibility». Today, as a person living in a large metropolis, consuming large amounts of energy and the benefits of a technocratic civilization, as well as a person living in the core of the wild nature, mercilessly cutting down forests, pouring mercury into rivers for the sake of gold cannot boast a high level of ecological culture. Their search for the utopia of the «ideal land» as the promised lands of «Zheryuk» and «Zhideli-Baysyn» and of the «ideal society», which lives without hunger, destitution, wars and social anomalies, seeking a single harmonious path in spiritual solidarity with nature, this core of the traditional worldview of a nomad, of his holy almost sacred attitude and worship to the Great Steppe, echoes with the concept of sustainable development.
\end{abstract}

Keywords: ecological culture, consumer culture, sustainable development, traditional cultures, utopia, philosophy.

\section{Introduction}

Many scientists are concerned about the problems facing modern humanity, as human survival is not possible unless the whole world community makes joint efforts to tackle environmental pollution. It is in the light of threats of a planetary scale, such as environmental disasters, global warming and others, that the issue of sustainable development has been given more attention. It should be noted that in recent decades, in addition to the voluntary renunciation of nuclear weapons, the Republic of Kazakhstan has raised many global issues - environmental security, dialogue of world's cultures and religions.

At the 62nd Session of the UN General Assembly, held on September 26-27, 2007 in New York, the President of the Republic of Kazakhstan, N.A. Nazarbayev raised the question of creating a register of environmentally unfavorable areas so that the global issue of environmental pollution could be tackled more systematically. Today, it is impossible to develop our world further without a global approach to economy, politics, and environmental issues; for this reason the topic of sustainable development should be broadly discussed.

It is true that there is a close correlation between globalization and sustainable development. However, there is also a contradiction between the trends of modern global processes: on the one hand, globalization creates the preconditions for instability, a threat to the world's security; on the other hand, it is one of the main ways to combine efforts of all states, to overcome instability and ensure the transition to sustainable development. In the late $60 \mathrm{~s}$ and early 70s of the last century, the members of the Club of Rome were first to pay attention to

\footnotetext{
${ }^{*}$ Corresponding author: davydofff888@gmail.com
} 
the global nature of many world's problems. Their reports laid the foundation for the concept of sustainable development of the world community.

The Commission on Sustainable Development (CSD) was created in December 1992 to ensure effective follow-up of UNCED, to monitor and report on implementation of the agreements at the local, national, regional and international levels. It was agreed that a five year review of Earth Summit progress would be made in 1997 by the United Nations General Assembly meeting in special session [1].

Developed on the basis of a search for the ways to overcome these threats, the reports of members of the Club of Rome, namely "The Limits to Growth" and "Beyond Growth" by Donella H. Meadows, Dennis L. Meadows and J. Randers, "Our Common Future" by the World Commission on Environment and Development, headed by G.H. Brundtland, and "Agenda 21" adopted by the UN Conference in Rio de Janeiro in 1992, became the foundation of the concept of world's sustainable development [2].

It is clear that globalization and global studies had to be created: the need to think globally was largely dictated by the harsh realities of our time. Unless every person, country, continent understand that the problems associated with human activity and the depletion of natural resources on Earth are the issues common for the whole world, they will continue to be pressing for the humanity in the future.

\section{Methodology}

The article is based on general scientific principles of historicism and objectivity. When writing this article, the authors relied on the principle of historicism, which considers any event in the prism of the past and the future. The comparative method made it possible to investigate the historical and philosophical analysis. The following methods were used: describing the individual characteristics of individual historical facts and events, problemchronological, reflecting facts and events in a logical sequence.

\section{Results and discussion}

\subsection{Some aspects of utopia in the Turkic worldview in the concept of sustainable development}

Sustainable development, as a concept of the world's development in harmony with the environment, is the key to solving many planetary problems, like global instability, poverty, overpopulation, soil, water and air pollution, climate change, deterioration of human health and other numerous environmental and social issues. Sustainable development means the way of development that would help humanity to avoid dying out as a result of selfdestroying barbaric actions affecting the environment. The process of transition to sustainable development requires large-scale and multifaceted actions: from a review of philosophical and worldview concepts, the reorganization of political systems, to specific environmental measures at all levels.

Today, be it a metropolis resident spending large amount of energy on a daily basis, or a person living in wild, mercilessly cutting down forests and pouring mercury into rivers while washing gold, - we all lack environmental culture. A sustainable society is incompatible with 
irrational human needs. Therefore, in order to ensure proper functioning of ecosystems, one should refuse from such overconsumption.

The transition to a sustainable society implies the consideration of environmental issues in human activity. People should be conscious enough to eliminate irrational consumption. Without this, environmental improvement and the mankind's survival are impossible.

Turkic folklore tells the story of the "promised land", the homeland of the ancestors, "heaven on earth" that people forgot the way to, since greed, envy and cruelty filled their hearts [12]. Turkic folklore tells the story of the "promised land", the homeland of the ancestors, "heaven on earth" that people forgot the way to, since greed, envy and cruelty filled their hearts [3]. For example, there are historical legends about the sacred land Otuken, which is repeatedly mentioned in the Orkhon inscriptions and works of Al-Biruni, Marvasi, Mahmud Kashgari. Ergenekon is considered to be the ancestral home of all Turkic peoples [4]. Ergenekon is not just a paradise on the earth; it is a place of interaction between man and nature, a place of power, a place of spiritual growth of a person as a component of sustainable development.

\subsection{The main components of sustainable development is an enabling social environment: the role of Kazakh zhyrau, which created ideal images of the ruler and society}

It is also worth noting that in a system of sustainable development time and space should be in equilibrium. The categories of space and time in Kazakh culture are uncovered in two ancient Turkic myths and legends associated with the images of wise men - wanderers. One of them is dedicated to the shaman Korkyt Ata, who escaped death, and the second one tells about Asan Kaigy, who was looking for the promised land of Zher Uiyk. Kazakhs highly valued Korkut as he was considered a patron of shamans (baksy), who often called him to help when carrying out shamanic rituals. During these rituals, many baksy were singing kui, composed by Korkyt" [13].

The most well-known ancient epic poem in Turkic language "Korkyt Ata" was created on the territory of Kazakhstan, in Kipchak - Oghuz area of the Syr-Darya basin in the 8-10th centuries and spread orally. It was not until the 14-16th centuries that it was recorded in a prose form as "Book of Korkyt Ata" by Azeri and Turkish writers.

Korkyt himself was a real person, a noble man of the Oghuz - Kipchak tribe Kiyat. In nomadic culture, the image of a person who devotes his life to the search for a happy peaceful life is very common, and Korkyt is among the most significant figures [4]. Legend has it that Korkyt could not accept the idea the transience of human life, so he decided to fight against inevitable death.

He created and played kobyz (musical instrument), expressing his thoughts about life with his music. He found his immortality in art. All birds and animals living in the promised land, winds and flowing rivers were listening to his music with bated breath. When the music stopped, the world created by him disappeared. Korkyt Ata.

Ch. Valikhanov considered the legend about Korkyt one of the major components forrning the Kazakh mentality; for him Korkyt was a shaman, a poet [5]. Korkyt Ata was among the first Turks who were trying to find a blessed land for his people. The native land "tugan zher" is the place where a person lives in harmony with himself, with the inner world, with the surrounding reality, inhaling the smell of native grass (zhusan), which returns a person to his origins and helps not to forget about his roots, giving sources of inspiration and world order. 
According to another ancient legend about Asan Kaigy (Sad Asan), the sage spent all his life in search of the promised land Zher Uiyk, but all his efforts were in vain. Asan Kaigy, riding his camel Zhelmaya, travelled to four sides of the world. He believed that there was a beautiful place Zher Uiyk, where people lived up to 100 years with no wars and hunger. For example, the teaching of Korkyt Ata was spread throughout the medieval Turkic world and all prominent figures of Central Asia knew his name [15].

According to the description, in this paradise there were many lakes and rivers, many pastures with dense grass, and the cattle was giving birth to young animals twice a year. A lark nesting on the back of a sheep became the symbol of happiness and peace.

Both sages, who went around the whole world, but never found a better life, a better place where humanity would live without problems and needs, or where a person could escape death, reaffirm the connection of life and death and the universe integrity. To interpret the ethnographic material, it is possible to use existing theoretical schemes which allow for reductionism. M. Auezov notes: "Asan is a sufferer who saw the vices of nomadism, and is a tragic utopian" [14].

"Kazakh zhyrau, a nomadic philosopher, steppe humanist, an influential adviser to Khan Ulug Muhammed (Ormanbet Khan), during the political struggle in the ulus of Abulkhair Khan, was on the side of the opposition - the sultans of Kerey and Zhanibek. Since the foundation of the Kazakh Khanate (1456), he became its main ideologist" [6]. "Zhyrau" means the narrator, which can be also broadly interpreted as "nomadic philosopher", "steppe humanist".

Zhyrau of 15-19th centuries defined the idea of justice. Kazakh zhyrau connected the idea of an ideal state with the idea of justice. Storytellers praised the rulers of the Kazakh Khanate, even idealized them, while also criticizing the khans and their policies at the same time. They were critical of rulers' actions in relation to the Kazakh Khanate and foreign policy.

Mukhtar Auezov highly praises Asan Kaigy in his research: "The search for the earthly paradise referred to in these stories has a deep social motive behind. Therefore, akyns, singing about difficult life conditions, first of all remembered his name" [7]. In traditional cultures, aesthetic taste, aesthetic perception of the world is associated with the desire for a person to unite with the world around him. This desire to live in harmony with the surrounding world was expressed in nature contemplation.

Nature for people had its soul and was animate. A man could not become an integral part of nature, but he could come close to its mighty power through self-education and contemplation of the world. That is why, traditional cultures are ecosophical in nature.

In general, people in traditional cultures tried to live in harmony with nature, its rhythms. These characteristics can also be attributed to the Kazakh traditional culture. The life of the Kazakh nomad was also largely determined by the natural rhythms. All life was seen by Kazakhs (as well as the Japanese) in the changing seasons: summer, autumn, winter, spring. Routine days and holidays - everything was built in accordance with the seasons. A person's lifestyle, his mood were connected with natural biorhythms. A man comes and leaves this world; only nature and the world are eternal. Understanding our finitude, the brevity of human life, and the need to find its meaning brought Kazakh people to the concept of "zhalgan dunie" (mortal coil). It expresses illusory, fragility, ephemerality, shows that 
everything in this world comes and goes. There are many similar ideas in Kazakh folk songs, for example, "Armanai, otedi dunie zhalganai"(How ephemeral the world is!).

Generations replace one other, and the course of life is like the course of a river. A central component of two legends is the idea of search for truth, while overcoming difficulties on the way. The concept of "zhol" (way) is not just wandering, but has a broader meaning of a "life path". Nomadic culture has always been associated with movement, dynamics. As A.Weber wrote, "the invasion of the nomadic people of Central Asia, who have reached China, India and the West (the great cultures of antiquity borrowed from them the use of horses), had... similar consequences in all three areas [8].

What is natural, was considered to be harmonious, therefore, beautiful. Even dwellings were tried to establish and equip so as not to disturb the beauty of the surrounding natural landscape, moreover to emphasize its beauty. The human being, as well as the whole system of his values, including the aesthetic perception of the world is inextricably linked to nature. That is, the human being is considered in ontological semantic context. The problem of understanding the essence and purpose of man is determined by the nature of this ontology. Kazakh zhyrau and akyns openly expressed their claims about the crisis state of Kazakh society and made an attempt to search for a new, harmonious world.

Finally, Asan visited Zhideli Baisyn. Having returned back home, he told others: "I found the place where you can ride a horse without fights, where cattle will not be stolen by thieves or eaten by wolves, where we will never be homeless. It is warm there, and we can live there all together" [16]. Mukhtar Auezov highly praises Asan Kaigy in his research: "The search for the earthly paradise referred to in these stories has a deep social motive behind. This is the long time dream of Kazakhs striving to build a new life [17].

The reason for the appearance of utopia in the context of the Kazakh traditional worldview, in our opinion, is the crisis of horse-nomadic civilization. Social and utopian ideas in the XV - XVIII centuries appeared in connection with the crisis of the socio-political system, the necessity of the idea of the Golden Age arose on the break of historical formations and as a result the role of zhyrau, which created ideal images of the ruler and society, the so-called "Zher Uyuk" and "Zhideli Baisyn". The utopia of Kazakh zhyrau is aimed at transforming the social order. Legends about "Zher Uyuk" and "Zhideli Baisyn" make an essence of the Kazakh steppe thinkers, in this case utopia carries out function to change the existing order on ideal bases.

Utopia in Kazakh world understanding is based on counter values, oppression, poverty, misconceptions, utopia tries to construct a life in which earthly happiness, reason, virtue, justice, independence can become possible in reality. Asan Kaigy, Korkyt Ata and others do not accept the world they live in, they strive for social harmony and perfect society. The new spiritualization of the legends of the promised land stems from reality, which has caused deep aversion and frustration. The justification of the utopia in this period of time was the idea to achieve "unity of life and being", how the life of man and society should be built and fulfilled in this difficult period for the Kazakh steppe as a whole.

We can state that the utopia of Kazakh zhyrau, singers, akyns performed not only the main gnoseological functions (the image of the "land of prosperity", the model of ideal social structure), and the highest values of human existence (justice, truth, happiness, goodness), which are to be implemented by man and society. 
The problems of the phenomenon of utopia are closely connected with the problems of ideology, historical dynamics and the nature of man. The events that took place in the life of Kazakhstan in the first decades of the twentieth century were closely connected with socioeconomic and political changes in Russia. The concept of sustainable development includes many characteristics. But the main one is the balance in all spheres of life. One of the main components of sustainable development is an enabling social environment. Another condition for sustainable development is care for the environment.

\subsection{The new era of Soviet utopia: on the example of Kazakhstan}

The Soviet history is the history of the endless construction of the city, the city in the taiga, the city on the virgin lands, the city on Mars and the Bolsheviks, declaring the goal of building a paradise on earth built this utopia at the cost of human lives. And the image of a bright future became farther and farther unreal. Four hundred years after the appearance of "Utopia" terrible predictions made by the wise Englishman Thomas More became a reality in the Soviet Union.

The communist utopia in the Soviet Union was defeated not by dissidents and advisors, but, aphoristically speaking, by three-programmers in the kitchen and a KVN lamp TV set, i.e. by the introduction of a mass television and radio broadcasting network, which, as a result of evolution, was supplemented by the possibility of re-recording sound and images on audio and video recorders, and then turned into satellite antennas and the Internet. The second great utopia was formed at the turn of the sixties and seventies. For educated, thinking and talented people of the "generation of 1960s", the world was divided into "Soviet" and "non-Soviet" zones, just as for their older brothers and sisters.

The new thing about communism was the proposal to build an ideal society not with the help of heavenly forces, but with the help of quite rational means and political mechanisms. This concept goes back to Plato with his "State". He also guessed the features of an ideal prosperous society in the "Atlantis". Each concept bore the seal of its own epoch and corresponding social and political ideas. Thus, Plato's every citizen of an ancient communist society had to be fully provided for, because he was entitled to at least three slaves. Campanella's "City of the Sun", where equality and harmony were supposed to flourish, was supposed to come to communism through a rigid repressive apparatus. Thomas More suggested similar measures in his Utopia, another version of the ideal social order.

The good intentions to build a new society were accompanied by the destruction of everything that was perceived as a legacy of the past. A lot of things were broken and a lot of things were built, but the ideal city never worked out. Either there was not enough strength to destroy everything. Or the system of values of the new state machine turned out to be too doubtful.

In the practice of "socialist construction" neither material well-being nor social justice were really achieved. National economic success, whether authentic or alleged, was often attributed to the colossal, miraculous, almost magical power of the communist idea and the specific activities of party leaders - the protagonists of this idea, which led to the creation of truly "paradisiacal" new buildings and oases-edemas, for example, in the steppes and deserts. These ideas were reflected in the works of Soviet "akyns" [9].

The comparison between Lenin and Luther, made by Yuri Furmanov, also seems to be productive: "Luther and Lenin are closely connected by that indestructible, almost mystical 
religious energy, with which they embodied the "truth" of Christ's and Marx's teachings. But neither of them even noticed in the heat of constant discussions that this "truth" is only an expression of their own doctrine.

Lenin made an attempt to build a socialist society and this is confirmed by one of the priorities of the party and the Soviet state to transfer the people who lagged behind in their development to the path of socialism, Lenin believed the destruction of all national and class privileges, the consistent implementation of the internationalist principle of full equality of all peoples, the uprooting of all remnants of the colonial past, in particular in land relations [10].

The Bolsheviks were distinguished by the desire to destroy all the old and to erect a new world of justice and equality on the ruins of the empire, to create a paradise on earth. Worldview and behavioral, Bolshevism is a peculiar combination of the most sublime fanatical faith with the lowest criminal psychology. The genius Dostoevsky guessed the prototype of the Bolshevik in his Raskolnikov, the murderer and robber, however, dreaming of New Jerusalem. Stalin was an expression, a symbol of a new round of Bolshevik utopian revolution. Stalin's sole assertion in power was the beginning of a new and no less large-scale (as compared to October) revolution marked by utopian Marxism (collectivization, mass repression, preparation for a new revolutionary world war).

Shy voices of scientists, saying that such development of new lands may turn out to be completely unjustified were not taken into account. On the contrary, everything was done very hastily. Guided by the directives of the Central Committee of the CPSU, the VII Congress of the Communist Party of Kazakhstan set a "major task" for the workers of the republic - to expand grain crops through the development of 6.3 million hectares of virgin and fallow lands. V.I. Lenin in his works of the Soviet period repeatedly returned to the idea of development of virgin lands, developing the principles of land use, forms and methods of involvement of new lands in agricultural circulation.

He pointed to the most important conditions for the systematic use of virgin lands and fallow lands - the creation of a powerful tractor park, the construction of railways. He personally contributed to the practical implementation of the idea of developing virgin lands in the first years of Soviet power. [9]. It is known that Lenin enthusiastically supported the initiative of St. Petersburg workers to create the first agricultural communes on virgin lands of Eastern Kazakhstan.

Large areas of land were ploughed up in pursuit of indicators. Disruption of the ecological balance caused severe results. Soil erosion was developing, fertile humus was weathered. Besides, plowing millions of hectares of land for sowing resulted in reduction of hay and pasture lands. In many works and publications of the 50-80s, the development of virgin lands, which represented the success of the Communist Party and the Soviet state, was not reflected in many miscalculations, distortions and overturns.

In the greeting of the CPSU Central Committee dedicated to the 30th anniversary of the heroic virgin epoch, it is noted that the rise of the virgin lands is one of the brightest pages "in the annals of the creative work of the party and people, the implementation of the agrarian policy of the CPSU, a convincing evidence of the advantages of the socialist system of management".

At the XXI Congress of the CPSU in 1959, N.S. Khrushchev proclaimed about the achievement of the complete victory of socialism and the onset of the period of "unfolded 
construction of a communist society" and according to N.S. Khrushchev the liberated energy of the Soviet people, will lead to the visible frontiers of communism.

The logic of capitalism, which, from the economic point of view, leaves open the possibility of cultural, educational, etc. Rises for the majority - a possibility still representing economic value - is also the logic of utopia as a "function of the real". If there is no room for such a possibility (the neo-feudal perspective looks more like an anti-utopia), this implies that the path of utopia as a "function of the real" is closed to the majority [11]. In 1960, wind erosion destroyed 9 million hectares of land in the northern regions of Kazakhstan, which was equal to the entire agricultural area of such a country as France [18].

Soviet Regime made an effort to create the Great Utopia, the society without private property where dominated social justice. Some unsuccessful utopian experiments failed since none spiritual efforts were made. The aim was to come to a paradise on the earth but practice turned to be worse that theory; internal state of people, centuries-long culture of the Kazakh people, mentality had not been taking into account.

\section{Conclusion}

Summing up the results of the research it is necessary to note that there was a philosophical and historical excursion into the worldview and ideology of the Turkic nations of Eurasia. As an example from the ancient history the legends about storytellers - wanderers, steppe sages such as Asan-Kaigy and Korkyt-Ata are studied, and as examples of history of the Soviet period there are utopian experiments in development of virgin and fallow lands.

To sum up, the transition to sustainable development requires a revision of values: the development of a sustainable consumption psychology among consumers, compliance with the code of social and environmental responsibility of business, and the adoption of specific environmental measures at all levels of government in all countries. The process of transition to sustainable development requires large-scale and diverse actions. Only "sustainable development" will allow mankind to avoid extinction from the Earth's face, caused by selfdestruction under the influence of barbaric actions in relation to the environment.

\section{References:}

1. United Nations Conference on Environment \& Development. Rio de Janerio, Brazil, 3 to 14 June 1992 AGENDA 21 Web https://sustainabledevelopment.un.org/outcomedocuments/agenda21

2. Chimitova, A.B., \& Mikulchinova E.A. (2007). Issues of sustainable and safe development of the regional economy. Ulan-Ude.

3. Turkish philosophy: Ten questions and answers. - A.: IPhP, 2006.-142 p.

4. Akatai, S. (2000). Asan - Kaigy: Epiphany and Mistakes. Thought. 11. 63-68.

5. Walikhanov, C. (1984). Collected Works in 5 - Volumes (Vol. 1, p. 432). Almaty: Kazakh Soviet Encyclopedia.

6. Anthology of pedagogical thought in Kazakhstan. A.: Rauan, 1995.- 512 p.

7. M.O. Auezov Shygarmalar. Volume II, A.: Zhazushy, 1969. -398 p.

8. Jaspers, K. (1994). The origin and goal of history. Moscow: Republic. 
9. Great October and socially-economic progress of Kazakhstan: (Historiography: experience and problems). A.-Science, 1987.-336 p.

10. Dahshleiger G.F. Socially-economic conversion in the auyl and village of Kazakhstan (1921-1929). A.: Science, 1965-536 p.

11. Fishman, L. (2017). Changing Societies \& Personalities, Vol. 1, No. 3.

12. Nysanbayev, A., Aupov, N., \& Gabitov T. (2006). Turkish philosophy: Ten questions and answers. Almaty: Institute for philosophy, political science \& religion studies.

13. Harner, M. (2007). Pilgrims of reality. World Monitor. 3 (7). 45-67.

14. Auezov, M. (1972). Time is the binder. Literary-critical sketches. Almaty: Jazushy.

15. Smirnova, N. (1951). Essays of Kazakh literature of the XVIII century. Almaty: Uchpedgiz.

16. Satpayeva, Sh., \& Adibayev, Kh. (1985). Kazakh literature. Almaty.

17. S.A. Kaskabasov Kazakh non-fairy tale prose. A.: Science, 1990.-240 p.

18. Zhanaidarov O. My Motherland is Kazakhstan. A.: Balausa, 2002.-160 p. 